\title{
Sustainability of maize-based cropping systems in rural areas of Zimbabwe: an assessment of the residual soil fertility effects of grain legumes on maize (Zea mays [L.]) under field conditions
}

\author{
Oniward Svubure $^{1 *}$, Sheunesu Mpepereki ${ }^{2}$ and Fred Makonese ${ }^{2}$ \\ ${ }^{1}$ Department of Irrigation and Water Engineering, Chinhoyi University of Technology, Off Harare-Chirundu Highway, P. Bag 7724, Chinhoyi, ZIMBABWE \\ ${ }^{2}$ Department of Soil Science and Agricultural Engineering, University of Zimbabwe, P. Bag MP 167, Mt. Pleasant, Harare, ZIMBABWE \\ E-mail addresses: osvub@yahoo.com, osvubure@cut.ac.zw (Oniward Svubure, ${ }^{*}$ Corresponding author), smpepe@agric.uz.ac.zw \\ (Sheunesu Mpepereki), fmakonese@agric.uz.ac.zw (Fred Makonese) \\ Tel.: +263 67 2203-5 or 29053-5; fax: +263 6728957 (direct line); Mobile: +263 772662122 (Oniward Svubure)
}

\begin{abstract}
The residual soil fertility benefits of the preceding legumes to the following maize crop were demonstrated in the study. Incorporating stover of Bambara nut, cowpea, groundnut dry bean and soyabean gave higher maize yields compared to plots where the stover was removed. Total maize dry matter yield increases of 1.30 tha- $^{-1}$ to 5.19 ha- $^{-1}$ were recorded following legume stover incorporation compared to stover removal. Even removal of stover of these same legumes gave significant maize yield increases compared to those from the maize after maize or after fallow plots. The total maize dry matter yield was greater after legumes with stover removed (ranging from 4.41 to 9.91 tha $^{-1}$ ) than after maize (2.16 to 2.26 tha $^{-1}$ ) or one season fallow (1.57 to 1.84 tha $^{-1}$ ). So farmers who keep livestock can still remove legume residues as fodder to supplement grazing in the dry winter period and still benefit from improved maize yields.
\end{abstract}

Keywords: Legume crops, residual soil fertility, maize-based cropping systems, sustainability, smallholder rural farmers, Zimbabwe.

\section{Introduction}

Leguminous plants can biologically fix atmospheric nitrogen $(\mathrm{N})$ so as to directly contribute to their $\mathrm{N}$ needs for grain and fodder production. The $\mathrm{N}$ in legume crop residues can benefit the following maize crop. Several scientists have reported soil fertility improvements through incorporation of residues from $\mathrm{N}_{2}$-fixing legumes. For example, notable work has been carried out by McDonagh et al. (1993) and Giller et al. (1997). Such deliberate practices of legume stover incorporation could lead to a reduction in the need for mineral $\mathrm{N}$ fertilizer application by smallholder farmers and further widen their gross margin in maize production. The $\mathrm{N}$ input obtained from biological nitrogen fixation (BNF) by grain legumes to indirectly benefit cereal grain production will depend on 3 factors. These are the BNF contribution of the legume crop, the proportion of $\mathrm{N}$ removed in the grain ( $\mathrm{N}$ harvest index), and the efficiency of transfer of the $\mathrm{N}$ in the residues to the nutrition of the subsequent cereal crop (Giller et al., 1993). Therefore management options to optimize all or some of these factors by researchers, agricultural extension workers and farmers must play a fundamental role in the long term sustainability of the $\mathrm{N}$ nutrient input in smallholder agriculture.

Substantial studies on legume rhizobial inoculation have also been conducted in the country (Mukurumbira, 1985; Mpepereki, 1994; Kasasa, 1998; and Svubure, 2000) but corresponding studies on the residual benefits of some legumes to maize have been limited. More research studies need to be done particularly on legume field husbandry to maximize the $\mathrm{N}$ input obtained from BNF to benefit the following maize crop. This research may include rhizobial inoculation, modest mineral fertilizer amendment especially phosphorus (P) and potassium (K) fertilizers and liming to correct soil acidity. This study was therefore conducted to assess the residual soil fertility benefits to maize growing Bambara nut, dry bean, groundnut and soyabean. The legumes were grown with rhizobial inoculation and moderate application of lime, P and K mineral fertilizers. 
The study hypothesized that crop residues of different legumes returned into the soil together with decomposing roots, nodules and fallen leaves provide a significant quantity of $\mathrm{N}$ which improves $\mathrm{N}$-uptake, growth and yield of the subsequent maize crop. This study was carried out to measure the effect of groundnut, dry bean soyabean and Bambara nut crop residues incorporated into the soil on the following maize crop with respect to: (i) grain and stover yield and (ii) total $\mathrm{N}$ accumulation in grain and stover.

Two varieties were used for each legume crop. These included a variety grown for a very long time in the local area for each legume code-named "local" and is now well adapted to the local growing environment. The varieties used for groundnut were Falcon and "Local", dry bean varieties were Natal Sugar and "Local", soyabean varieties were Roan and "Local" and Bambara nut varieties were "Local mixed" and a Government certified variety. The maize crop was planted in rotation to these legume crops in the subsequent season.

\section{Materials and methods}

2.1 Experimental design: This experiment was carried out at Chigondo and Nyamhemba sites in the 1998/99 cropping season. Chigondo and Nyamhemba sites are located in the central part of Wedza district in Mashonaland East province of Zimbabwe. Soil samples were collected for analysis. The physical and chemical characteristics of the soils were determined in the laboratory using written standard procedures developed from published methods. For each soil characteristic determined, 4 replicates were used and the mean result calculated and recorded. The soils were analyzed mainly for $\mathrm{pH}$, texture, CEC, organic carbon, total $\mathrm{N}$, available Phosphorus and the exchangeable bases. Rain gauges were installed at the experimental sites to recorded received rainfall throughout the growing season. At both sites, the maize was planted superimposed on plots planted to the legume crops in the previous season (1997/98) rhizobial inoculation response trials, giving a split-split plot randomized experimental design. The main plots were the inoculation and no-inoculation treatments, the subplots being the different legumes grown. Each subplot split into 2 equal halves to give the sub-plots with legume stover incorporated in one half and removed in the other half. The size of the subplots was $5 \mathrm{~m} \times 5 \mathrm{~m}$ and the sub-subplots were $2.5 \mathrm{~m}$ x $5 \mathrm{~m}$. Plots which were left fallow and those planted to maize in the previous 1997/98 season were also planted to maize (1998/99 season) and served as the control plots. The maize after fallow or after maize rotational practice is commonly done by communal farmers in Zimbabwe. Land is sometimes left fallow mainly due to perceived soil fertility 'rebuilding'. The maize after maize rotation is done partly because of arable land shortage and that maize is the staple food crop. The legumes stover was dug-in approximately to within the top $15 \mathrm{~cm}$ of the surface by hand using a hoe soon after harvesting the grain when the ground was still soft. On the other half of the plot, stover was removed. Picking up of fallen leaves in the minus (-) stover plots started early as soon as leaf senescence and fall began. Similar digging was done on the (-) stover plots to simulate winter ploughing commonly practiced by farmers to basically control weeds among other things, and also to remove any land preparation treatment effects between the $(+)$ and $(-)$ stover plots.

Planting rains fell in the third week of November 1998. The Seed Co. Ltd bred maize cultivar SC403, which is early maturing and drought stress tolerant was planted at both sites. At Chigondo planting was done on 26 November and on the following day at Nyamhemba. No conventional ploughing was done at both sites. Planting furrows $0.9 \mathrm{~m}$ apart were opened by hoe and 3 maize seeds were dropped per station along the furrow and immediately covered to a depth of about $5 \mathrm{~cm}$. Spacing within the row was $0.3 \mathrm{~m}$ between stations. Thinning was done to 1 plant per station 1 week after emergence to remain with an even crop stand equivalent to 37037 plants per hectare. Minor maize stalk borer (Busseola fusca) infestation occurred at some Chigondo plots. Effective control was achieved through one spot application on affected plants with thiodan $1 \%$ granular. Hand weeding by hoe was done twice at both experimental sites and the plots were generally weed free. No mineral fertilizer was applied. In the preceding season, the legumes were planted with modest mineral fertilizer applications which were sprinkled in the planting furrows at a rate of $12.5 \mathrm{kgNha}^{-1}, 19.8 \mathrm{kgPha}^{-1}, 20.8 \mathrm{kgKha}^{-1}$ and liming at $300 \mathrm{kgha}^{-1}$.

2.2 Harvesting: After reaching physiological maturity stage, the plants were left to field dry for about 2 weeks. Harvesting on both sites was done on 27 March 1999. In each sub-subplot, one row on either side of a plot was left out as guard rows leaving 3 rows for harvesting. One plant at both ends of each of the 3 rows was also left out to remain with a total of 18 plants from each subsubplot for harvesting. The maize stalks were cut at the soil surface and the maize cobs were removed leaving the husks on the stalks. The maize stalks were weighed and sub-samples taken. The cobs were shelled and the grain weighed and sub-samples were taken as well. The maize stover and grain sub-samples were weighed and dried at $70^{\circ} \mathrm{C}$ for $24 \mathrm{~h}$ after which they were weighed again for moisture content determinations used to adjust the maize yields.

All the dried sub-samples were ground to pass through a $1 \mathrm{~mm}$ sieve using a laboratory hammer-mill. The samples were used to determine the total grain and stover $\mathrm{N}$ accumulation by the standard Kjeldahl method. In the standard Kjeldahl method, the organic $\mathrm{N}$ in the sample is converted to $\mathrm{NH}_{4}{ }^{+}-\mathrm{N}$ by digestion with concentrated $\mathrm{H}_{2} \mathrm{SO}_{4}$, and the $\mathrm{NH}_{4}{ }^{+}-\mathrm{N}$ is calculated from the $\mathrm{NH}_{3}$ distillation of the digest with alkali.

2.3 Data analysis: All data was subjected to an analysis of variance of treatment means using the 'Genstat' statistical package. Means were separated at a probability of $\mathrm{p}<0.05$. 


\section{Results}

3.1 Soil properties and rainfall: Selected characteristics of the soils at both study sites are summarized in Table 1 below. Rainfall received in the 1998/99 cropping season was 902 and 874mm at Chigondo and Nyamhemba sites respectively. Table 2 below summarizes the monthly rainfall totals received during the entire growing season.

Table 1. Selected soil characteristics at Chigondo and Nyamhemba experimental sites, 1998/99 cropping season.

\begin{tabular}{|c|c|c|}
\hline \multirow[t]{2}{*}{ Soil parameter } & \multicolumn{2}{|c|}{ Experimental site } \\
\hline & Chigondo & Nyamhemba \\
\hline Clay, \% & 13.80 & 4.50 \\
\hline Silt, \% & 9.70 & 4.80 \\
\hline Sand, \% & 76.50 & 90.70 \\
\hline Soil texture & Sandy Loam & Sand \\
\hline Organic C, \% & 0.60 & 0.58 \\
\hline Total N, \% & 0.06 & 0.05 \\
\hline Available P, mg/kg & 0.05 & 0.05 \\
\hline Exchangeable $\mathrm{Na}, \mathrm{cmol}_{\mathrm{c}} \mathrm{kg}^{-1}$ & 0.29 & 0.31 \\
\hline Exchangeable $\mathrm{K}, \mathrm{cmol}_{\mathrm{c}} \mathrm{kg}^{-1}$ & 0.65 & 0.89 \\
\hline Exchangeable $\mathrm{Mg}, \mathrm{cmol}_{\mathrm{c}} \mathrm{kg}^{-1}$ & 0.25 & 0.39 \\
\hline Exchangeable $\mathrm{Ca}, \mathrm{cmol}_{\mathrm{c}} \mathrm{kg}^{-1}$ & 1.16 & 1.31 \\
\hline CEC, $\mathrm{cmol}_{\mathrm{c}} \mathrm{kg}^{-1}$ & 5.31 & 4.92 \\
\hline $\mathrm{pH}$ (in $0.01 \mathrm{M} \mathrm{CaCl}_{2}$ ) & 4.90 & 5.90 \\
\hline
\end{tabular}

Table 2. Rainfall recorded at the Chigondo and Nyamhemba experimental sites during the 1997/98 and 1998/99 cropping seasons.

\begin{tabular}{|l|c|c|c|c|}
\hline \multirow{2}{*}{ Month/season } & \multicolumn{3}{|c|}{ Experimental site [monthly rainfall in millimeters, mm] } \\
\cline { 2 - 5 } & \multicolumn{3}{|c|}{ Chigondo } & \multicolumn{2}{c|}{ Nyamhemba } \\
\cline { 2 - 5 } & $\mathbf{1 9 9 7 / 9 8}$ & $\mathbf{1 9 9 8 / 9 9}$ & $\mathbf{1 9 9 7 / 9 8}$ & $\mathbf{1 9 9 8 / 9 8}$ \\
\hline October & 8.8 & 4.5 & 18.5 & 10.1 \\
\hline November & 144.3 & 137.0 & 94.2 & 106.5 \\
\hline December & 105.2 & 96.7 & 55.1 & 128.4 \\
\hline January & 301.7 & 271.2 & 271.4 & 252.4 \\
\hline February & 166.2 & 144.5 & 202.6 & 192.7 \\
\hline March & 121.1 & 89.4 & 78.4 & 116.8 \\
\hline April & 18.6 & 158.9 & 41.7 & 67.2 \\
\hline Totals & $\mathbf{8 6 5 . 9}$ & $\mathbf{9 0 2 . 2}$ & $\mathbf{7 6 1 . 9}$ & $\mathbf{8 7 4 . 1}$ \\
\hline
\end{tabular}

3.2 Maize grain and stover yields: Maize grain increased significantly due to legume stover incorporation at both sites (Tables 3 and 4). The maize grain yield increases varied depending on legume type. At Chigondo, the maize grain yield significantly increased following inoculation of the preceding soyabean Roan legume variety (Table 3). The grain maize yield range at both sites was from 2.64 tonnes per hectare $\left(\right.$ tha $\left.^{-1}\right)$ due to incorporation of Natal Sugar bean stover to 5.18tha ${ }^{-1}$ following incorporation of Bambara nut stover.

The maize stover yield was significantly increased due to legume stover incorporation at both sites (Tables 3 and 4). The increase also depended on the legume crop type. The average maize stover yields at Chigondo following the legumes with and without stover incorporation were 5.32tha ${ }^{-1}$ respectively; whereas at Nyamhemba the yields with and without stover incorporation were 5.73tha ${ }^{-1}$ and 4.74 tha $^{-1}$. The total $\mathrm{N}$ incorporated into the soil through the legume stover ranged from $18 \mathrm{kgNha}^{-1}$ in $A$. hypogaea "Local" variety at Nyamhemba (Table 4) to $67 \mathrm{kgNha}^{-1}$ in G. max "Local" variety at Chigondo (Table 3). At study sites, maize grain and stover yields following the legumes with or without stover incorporation were consistently higher than those from the 2 control plots (maize after maize and maize after fallow).

3.3 Maize grain and stover total $N$ accumulation: At Nyamhemba, total maize grain $\mathrm{N}$ increased significantly due to stover incorporation but varied with the legume crop type (Table 6). The maize grain $\mathrm{N}$ accumulation response to stover incorporation at Chigondo (Table 5) was dependant on inoculation and legume crop type in the previous season (an inoculation x legume x stover interaction effect). Across both sites, the total maize grain $\mathrm{N}$ content ranged from 17.5 to $41.4 \mathrm{kgNha}^{-1}$ where the legumes stover were removed and from 34.5 to $79.0 \mathrm{kgNha}^{-1}$ where the legumes stover were incorporated. The total grain $\mathrm{N}$ content in the maize after maize and in the maize after fallow control plots at both sites were consistently less than the ones in the maize following the legumes with or without stover incorporation. The maize stover $\mathrm{N}$ accumulation at both sites increased significantly due to the legume stover incorporation. The increase in maize stover yield depended also on the legume crop type. At Chigondo, the maize 
stover $\mathrm{N}$ content ranged from 9.4 to $24.0 \mathrm{kgNha}^{-1}$ where the legume stover were removed and from 16.7 to $47.5 \mathrm{kgNha}^{-1}$ where the legume stover was incorporated (Table 5). The maize stover $\mathrm{N}$ accumulation at Nyamhemba ranged from 13.0 to $40.2 \mathrm{kgNha}^{-1}$ where the legume stover were removed and from 18.2 to $51.1 \mathrm{kgNha}^{-1}$ where the legumes stover was incorporated (Table 6). With or without the legumes stover incorporation, the total maize stover $\mathrm{N}$ contents were consistently higher than those from the maize after maize or maize after fallow control plots (Tables 5 and 6). Both maize dry matter yield and total $\mathrm{N}$ uptake increased linearly in response to legume residue $\mathrm{N}$ added (Fig. below). As legume residue $\mathrm{N}$ added increased beyond $40 \mathrm{kgNha}^{-1}$, the curve flattened out as the increases in both maize dry matter yield and total $\mathrm{N}$ uptake became minimal. Dry matter accumulation rate was estimated to be 0.1 tonnes per kilogram $\mathrm{N}$ taken up, whereas total maize $\mathrm{N}$ accumulated at an approximate rate of nearly $1 \frac{1 / 2}{2}$ times the above-ground legume residue $\mathrm{N}$ added (Fig. below).

Table 3. Maize yield at Chigondo (1998/99 season) as influenced by preceding legume crop with and without stover incorporation

\begin{tabular}{|c|c|c|c|c|c|c|c|c|c|c|}
\hline \multirow[t]{2}{*}{$\begin{array}{l}\mathbf{U} \\
\mathbf{I} \\
\mathbf{r}\end{array}$} & \multirow[t]{2}{*}{$\begin{array}{l}\text { legume } \\
\text { inoculation } \\
\text { response }\end{array}$} & \multirow[t]{2}{*}{$\begin{array}{c}\text { Legume } \\
\text { crop/variety }\end{array}$} & \multirow[t]{2}{*}{$\begin{array}{c}\text { Stover } \\
\text { incorporated } \\
\text { [t/ha] }\end{array}$} & \multirow[t]{2}{*}{$\begin{array}{c}\text { Total stover } \mathbf{N} \\
\text { incorporated } \\
\text { [kg/ha] }\end{array}$} & \multicolumn{2}{|c|}{$\begin{array}{c}\text { Maize grain } \\
\text { yield [t/ha] }\end{array}$} & \multicolumn{2}{|c|}{$\begin{array}{l}\text { Maize stover } \\
\text { yield [t/ha] }\end{array}$} & \multicolumn{2}{|c|}{$\begin{array}{c}\text { Total maize } \\
\text { DM yield } \\
\text { [t/ha] }\end{array}$} \\
\hline & & & & & -stover & +stover & -stover & +stover & -stover & +stover \\
\hline \multirow{3}{*}{$(+)$} & & Roan & 4.32 & 45 & 3.98 & 4.70 & 5.00 & 6.17 & 8.89 & 10.87 \\
\hline & & Local & 6.23 & 61 & 3.10 & 4.97 & 4.04 & 6.81 & 7.14 & 11.78 \\
\hline & & P. vulgaris & & & & & & & & \\
\hline \multirow[t]{5}{*}{$(-) \mathrm{I}$} & $(-)$ inoc & G. $\max$ & & & & & & & & \\
\hline & & Roan & 2.08 & 20 & 3.15 & 3.62 & 4.16 & 4.99 & 7.31 & 8.61 \\
\hline & & Local & 7.09 & 67 & 3.11 & 4.82 & 4.18 & 7.66 & 7.29 & 12.48 \\
\hline & & P. vulgaris & & & & & & & & \\
\hline & & Natal Sugar & 2.86 & 33 & 1.73 & 2.89 & 2.82 & 4.02 & 4.55 & 6.91 \\
\hline M & $\begin{array}{l}\text { maize after } \\
\text { fallow }\end{array}$ & & & & 0.62 & & 1.22 & & 1.84 & \\
\hline
\end{tabular}

$\mathrm{DM}=$ dry matter; $\mathrm{N}=$ nitrogen; sed = standard error of deviation of means; $\mathbf{d f}=$ degrees of freedom; $(-)=$ minus; $(+)=$ plus; inoc = inoculation

Table 4. Maize yield at Nyamhemba (1998/99 season) as influenced by preceding legume crop with and without stover incorporation.

\begin{tabular}{|c|c|c|c|c|c|c|c|c|c|}
\hline \multirow[t]{2}{*}{$\begin{array}{l}\text { L legume } \\
\text { I inoculation } \\
\text { r response }\end{array}$} & \multirow[t]{2}{*}{$\begin{array}{c}\text { Legume } \\
\text { crop/variety }\end{array}$} & \multirow[t]{2}{*}{$\begin{array}{c}\text { Stover } \\
\text { incorporated } \\
\text { [t/ha] }\end{array}$} & \multirow[t]{2}{*}{$\begin{array}{c}\text { Total stover } \\
\mathrm{N} \text { incorporated } \\
\text { [kg/ha] }\end{array}$} & \multicolumn{2}{|c|}{$\begin{array}{c}\text { Maize grain } \\
\text { yield [t/ha] }\end{array}$} & \multicolumn{2}{|c|}{$\begin{array}{c}\text { Maize stover } \\
\text { yield [t/ha] }\end{array}$} & \multicolumn{2}{|c|}{$\begin{array}{c}\text { Total maize } \\
\text { DM yield } \\
\text { [t/ha] }\end{array}$} \\
\hline & & & & -stover & +stover & -stover & +stover & -stover & +stover \\
\hline \multirow[t]{6}{*}{$\left(^{+}\right) \quad(+)$ inoc } & A.hypogaea & & & & & & & & \\
\hline & Falcon & 1.31 & 18 & 2.51 & 3.47 & 3.42 & 4.24 & 5.93 & 7.71 \\
\hline & Local & 1.29 & 18 & 2.73 & 3.13 & 4.02 & 5.07 & 6.75 & 8.20 \\
\hline & V. subterranea & & & & & & & & \\
\hline & Bambarra 1 & 2.68 & 46 & 4.09 & 5.16 & 5.82 & 6.63 & 9.91 & 11.79 \\
\hline & Local mixed & 2.87 & 53 & 4.29 & 5.18 & 5.33 & 6.36 & 9.62 & 11.54 \\
\hline \multirow[t]{6}{*}{$(-) \quad(-)$ inoc } & A.hypogaea & & & & & & & & \\
\hline & Falcon & 1.13 & 18 & 4.01 & 4.31 & 4.68 & 5.20 & 8.69 & 9.51 \\
\hline & Local & 1.25 & 23 & 3.34 & 4.37 & 4.70 & 5.47 & 8.04 & 9.84 \\
\hline & V. subterranea & & & & & & & & \\
\hline & Bambarra 1 & 1.89 & 34 & 3.50 & 4.82 & 4.94 & 6.32 & 8.44 & 11.14 \\
\hline & Local mixed & 2.03 & 40 & 4.10 & 5.16 & 4.98 & 6.44 & 9.08 & 11.60 \\
\hline Se $(\mathrm{df}=16)$ & & & & 0.106 & & 0.105 & & 0.121 & \\
\hline M maize after & & & & 0.84 & & 1.42 & & 2.26 & \\
\hline \multicolumn{10}{|l|}{$\mathrm{M}$ maize } \\
\hline maize & & & & 0.49 & & 1.08 & & 1.57 & \\
\hline $\begin{aligned} & \text { after } \\
\text { fa } & \text { fallow }\end{aligned}$ & & & & & & & & & \\
\hline
\end{tabular}


Table 5. Nitrogen accumulation in maize seed and stover at Chigondo (1998/99 season) as influenced by preceding legume crop with and without stover incorporated.

\begin{tabular}{|c|c|c|c|c|c|}
\hline $\begin{array}{ll}\mathbf{L} & \text { legume } \\
\text { I } & \text { inoculation } \\
\mathbf{r} & \text { response }\end{array}$ & $\begin{array}{c}\text { Legume } \\
\text { crop/variety }\end{array}$ & $\begin{array}{c}\text { Stover } \\
\text { incorporated } \\
\text { [t/ha] }\end{array}$ & $\begin{array}{c}\text { Total stover } \mathbf{N} \\
\text { incorporated } \\
\text { [kg/ha] }\end{array}$ & $\begin{array}{l}\text { Maize grain N } \\
\left.\text { [kgNha }^{-1}\right]\end{array}$ & $\begin{array}{l}\text { Maize stover } \\
\mathrm{N}\left[\mathrm{kgNha}^{-1}\right]\end{array}$ \\
\hline
\end{tabular}

r response

-stover +stover -stover +stover -stover +stover

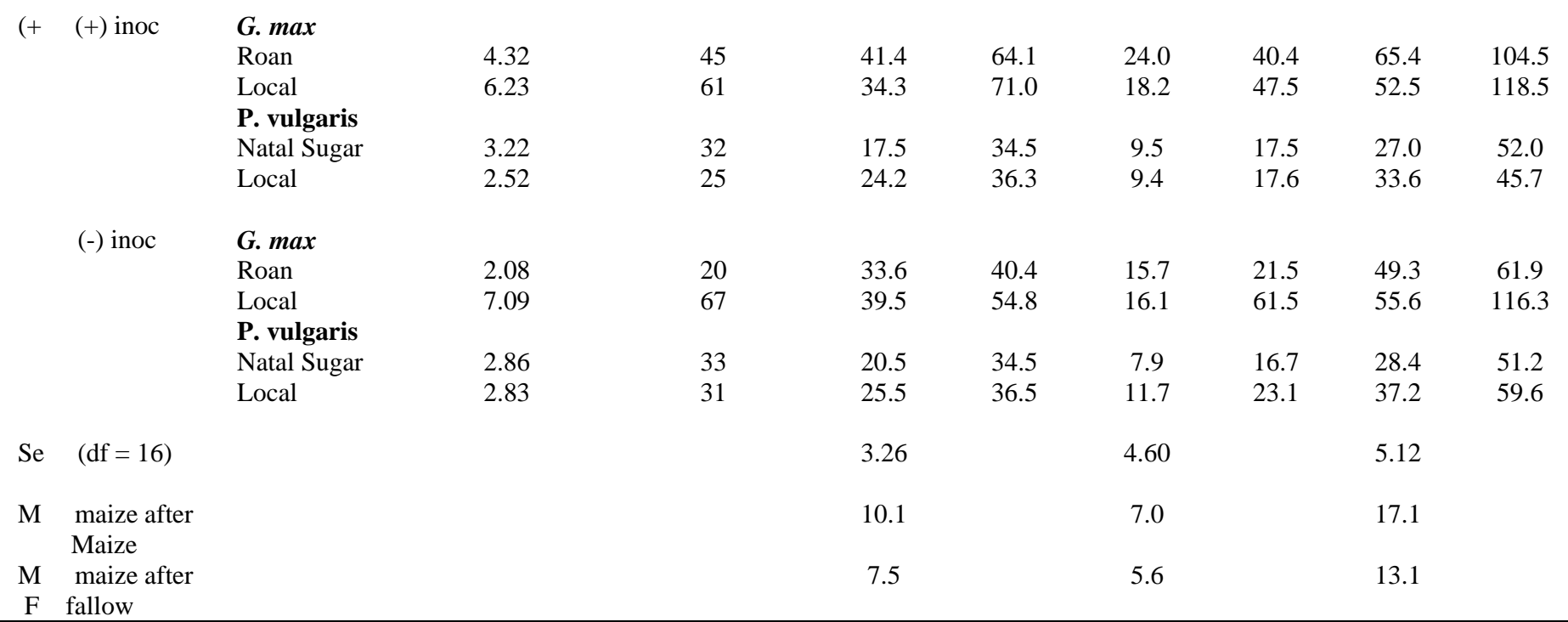

DM = dry matter; $\mathbf{n}$ = Nitrogen; sed = standard error of deviation of means; $\mathbf{d f}=$ degrees of freedom; $(-)=$ minus; $(+)=$ plus; inoc = inoculation

Table 6. Nitrogen accumulation in maize seed and stover at Nyamhemba (1998/99 season) as influenced by preceding legume crop with and without stover incorporated.

\begin{tabular}{|c|c|c|c|c|c|c|c|c|c|c|}
\hline \multirow{2}{*}{$\begin{array}{l}\mathbf{L} \\
\mathbf{I} \\
\mathbf{r}\end{array}$} & \multirow{2}{*}{$\begin{array}{l}\text { legume } \\
\text { inoculation } \\
\text { response }\end{array}$} & \multirow[t]{2}{*}{$\begin{array}{c}\text { Legume } \\
\text { crop/variety }\end{array}$} & \multirow{2}{*}{$\begin{array}{c}\text { Stover } \\
\text { incorporated } \\
\text { [t/ha] }\end{array}$} & \multirow{2}{*}{$\begin{array}{c}\text { Total stover } \mathbf{N} \\
\text { incorporated } \\
\text { [kg/ha] }\end{array}$} & \multicolumn{2}{|c|}{$\begin{array}{l}\text { Maize grain } \\
\mathrm{N}\left[\mathrm{kgNha}^{-1}\right]\end{array}$} & \multicolumn{2}{|c|}{$\begin{array}{l}\text { Maize stover } \\
\mathrm{N}\left[\mathrm{kgNha}^{-1}\right]\end{array}$} & \multicolumn{2}{|c|}{$\begin{array}{l}\text { Total N } \\
{\left[k_{\text {kgNha }}{ }^{-1}\right]}\end{array}$} \\
\hline & & & & & -stover & +stover & -stover & +stover & -stover & +stover \\
\hline \multirow[t]{6}{*}{(} & $(+)$ inoc & A.hypogaea & & & & & & & & \\
\hline & & Falcon & 1.31 & 18 & 26.8 & 43.2 & 13.0 & 18.2 & 39.8 & 61.4 \\
\hline & & Local & 1.29 & 18 & 30.9 & 38.6 & 19.9 & 26.6 & 50.8 & 65.2 \\
\hline & & V. subterranea & & & & & & & & \\
\hline & & Bambarra 1 & 2.68 & 46 & 54.6 & 78.0 & 40.2 & 51.1 & 94.8 & 129.1 \\
\hline & & Local mixed & 2.87 & 53 & 54.5 & 75.1 & 29.7 & 44.8 & 84.2 & 119.9 \\
\hline \multirow[t]{6}{*}{$(-$} & $(-)$ inoc & A.hypogaea & & & & & & & & \\
\hline & & Falcon & 1.13 & 18 & 47.7 & 55.0 & 22.7 & 29.9 & 70.4 & 84.9 \\
\hline & & Local & 1.25 & 23 & 40.3 & 55.5 & 25.6 & 34.7 & 65.9 & 90.2 \\
\hline & & V. subterranea & & & & & & & & \\
\hline & & Bambarra 1 & 1.89 & 34 & 46.9 & 68.4 & 22.5 & 45.8 & 69.4 & 114.2 \\
\hline & & Local mixed & 2.03 & 40 & 52.9 & 79.0 & 27.6 & 46.9 & 80.5 & 125.9 \\
\hline sed & $(\mathrm{df}=16)$ & & & & 4.27 & & 3.65 & & 5.73 & \\
\hline & maize after & & & & 10.7 & & 8.1 & & 18.8 & \\
\hline $\mathrm{m}$ & maize & & & & & & & & & \\
\hline M & maize after & & & & 6.2 & & 5.3 & & 11.5 & \\
\hline F & fallow & & & & & & & & & \\
\hline
\end{tabular}

DM = dry matter; $\mathrm{N}=$ nitrogen; sed = standard error of deviation of means; $\mathrm{df}=$ degrees of freedom; $(-)=$ minus; $(+)=$ plus; inoc = inoculation 

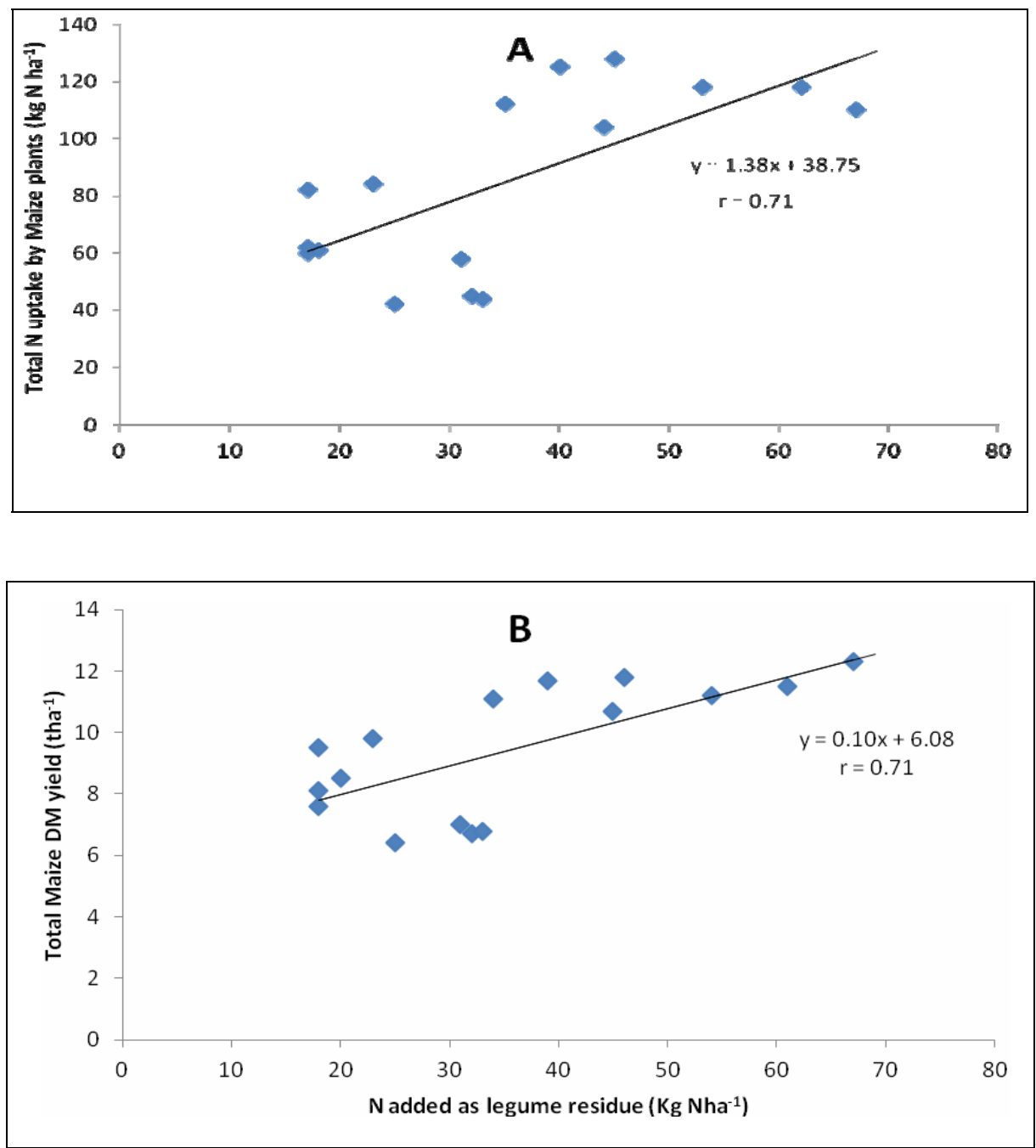

Figure 1. Effect of legume residue $\mathrm{N}$ on maize grown during the 1998/99 cropping season at Chigondo and Nyamhemba with respect to (A) total $\mathrm{N}$ uptake and (B) dry matter (DM) yield.

\section{Discussion}

The incorporation of the legumes stover at the end of the 1997/98 cropping season led to an increase in grain and stover yield and N-uptake by the maize crop grown in the subsequent 1998/99 season. The higher yield and increased N uptake by the maize appears to be directly related to the greater availability of soil $\mathrm{N}$ possibly resulting from the decomposition of the incorporated legumes residue. Organic matter content from the decomposing legume residues could have improved the chemical properties of the soil important to good plant growth. Improved soil properties such as water holding capacity, cation exchange capacity and mineralization of other plant nutrients could have also contributed to the increased maize yields apart from the increased soil $\mathrm{N}$ availability. There was no such effect to the maize grown after maize or after fallow control plots suggesting that these rotational practices' contribution to residual soil fertility, if any, have been minimal.

The results of this experiment also demonstrate that the benefit to the maize crop from previous cropping with a legume differed widely according to the nature of the legume. This was probably due to differences in plant total $\mathrm{N}$ uptake and nitrogen harvest indices by the legume leading to varying total stover $\mathrm{N}$ content. The incorporated $\mathrm{N}$ ranged from $18 \mathrm{kgNha}^{-1}$ in groundnut 'Local' stover at Nyamhemba to $67 \mathrm{kgNha}^{-1}$ in soyabean 'Local' stover at Chigondo (Tables 3 and 4). The high maize yields and $\mathrm{N}$ accumulation recorded in the maize grown following the traditional legumes Bambara nut 'Local mixed', groundnut 'Local' and Falcon and the promiscuous soyabean variety 'Local' was also probably due to the characteristically low nitrogen harvest indices of these legumes (Giller and Cadisch, 1995). The nitrogen harvest index (NHI) for this group of legumes ranged from 0.27 to 0.58 (Svubure, 2000). The low nitrogen harvest indices for these legumes suggested that the proportion of $\mathrm{N}$ available in residues for transfer to subsequent crops in rotation is high (Giller et al., 1997). Toomsan et al. (1995) reported similar results of a net 
contribution of $\mathrm{N}$ by growing groundnut (NHI, 30 to $60 \%$ of shoot tissue) as opposed to a net removal of $\mathrm{N}$ by growing soyabeans (NHI, 88\%) in studies in NE Thailand.

The yield of maize grown with stover incorporation was greater after Bambara nut 'Local mixed' (5.18 tha ${ }^{-1)}$, than after soyabean Local $\left(4.79\right.$ tha $\left.^{-1}\right)$, groundnut 'Local', $\left(4.37 \mathrm{tha}^{-1}\right)$ or Natal Sugar bean (2.89tha $\left.{ }^{-1}\right)$. The differences in the residual effects to maize by the different legume residues could be due to the combined effects of the amount of $\mathrm{N}$ input from biological nitrogen fixation by the legume, the amount of crop residue production, the NHI and the degree of lignification (\% lignin content) in the residues. A high NHI suggests that a greater proportion of the legume $\mathrm{N}$ has been translocated to the harvestable grain (as described above). However more research is needed to possibly explain the differences in the residual effects to maize by legume type.

The efficiency of the transfer of $\mathrm{N}$ derived from the incorporate legume residues to the maize plants is not $100 \%$. Some of the mineralized $\mathrm{N}$ is lost from the soil through leaching, soil erosion, volatilization and denitrification while some becomes part of the recalcitrant organic matter (Giller and Wilson, 1991). The legume residues were dug-in in the top $15 \mathrm{~cm}$ soil and this could have hastened the mineralization rate as opposed to where most of the residues are retained on the surface (in reduced tillage systems) which may delay the mineralization rate and probably increase the efficiency of transfer of legume residue $\mathrm{N}$ to the subsequent maize crop. Maize yield and N-uptake from the plots where legumes stover were removed were higher than those of the maize after maize or after fallow control plots (Tables 3 to 6). The $\mathrm{N}$ in the below ground legume residues (senesced roots and nodules) plus from leaves which fell before harvesting and could not be picked up, most likely accounted for this maize yield and N-uptake difference. The total residual below ground $\mathrm{N}$ is reported to be less than $10 \%$ of the total plant $\mathrm{N}$ based on maximum root biomass (Kipe-Nolt and Giller, 1993). May be this quantity $(<10 \%)$ is a large under-estimate of the true residual $\mathrm{N}$ benefit from belowground legume residues. This is so partly because root turnover from root growth and senescence leave much more $\mathrm{N}$ in the soil than is present in live tissue at any one time (Boddey et al., 1997). Peoples and Herridge (2000) also reported that the $\mathrm{N}$ in below the ground legume residues has been under-estimated and is not insignificant as previously thought. The residual $\mathrm{N}$ benefits of the below the ground legume residues probably explains the sometimes narrow differences in dry matter yield and $\mathrm{N}$ up-take by the maize plants in the (-) and (+) legume stover plots (Tables 3 to 6). The figure above showed that the maize plants' total $\mathrm{N}$ off take is much more than the legume residue $\mathrm{N}$ added. Probably the difference or part of the additional total maize $\mathrm{N}$ is contributed by the below-ground legume residues. The same figure above also suggests that beyond the $40 \mathrm{kgNha}^{-1}$ residue incorporation, the soils' potential or capacity to support the maize crop is attained. Alternatively, probably other limiting factors beside $\mathrm{N}$ become more important (beyond the 40kgNha ${ }^{-1}$ rate). For example soil texture, (Nyamhemba and Chigondo soils contain 91\% and 77\% sand respectively), $\mathrm{pH}$ and other nutrients. The high sand fraction and low CEC for both Nyamhemba and Chigondo soils (Table 1) suggests that $\mathrm{N}$ losses through leaching will be high, reducing the benefits of the maize crop from increased legume residue $\mathrm{N}$ additions.

Another contributory factor to the increased maize yields and $\mathrm{N}$-uptake in the (-) stover plots over the maize after maize or after fallow control plots could be the sparing effect of soil $\mathrm{N}$ by the $\mathrm{N}$-fixing legumes in the preceding season (Giller and Wilson, 1991). Graminaceous crops are usually much more competitive than legumes for soil nitrogen and the latter tend to obtain a greater proportion of its nitrogen requirement from BNF. Hence less residual $\mathrm{N}$ may have been available for the maize crop in the preceding maize and fallow plots than in the legume plots with stover removed.

The results of this study showed that communal farmers could still improve their maize yields by growing it in rotation with Bambara nut, groundnut, dry bean and soyabean even with stover removed. It is widely recognized that communal farmers remove and store up crop residues as livestock supplementary fodder during winter when veldt grazing becomes scarce. It may be worthwhile not to discourage the practice altogether since livestock are an important enterprise in communal agriculture. Farmers are encouraged to consider either incorporating the legume crops residues or removing them as livestock feed. Incorporating the legume stover would optimize their subsequent maize grain yield. On the other hand, the farmers would still improve their maize grain when the legume crop residue is removed and have an additional benefit of legume residue fodder for winter maintenance of livestock (cattle). A further study to establish the economic benefit of either incorporating all legume stover, complete removal or a balance between the stover quantities to incorporate and remove may be worthwhile.

\section{Conclusions}

Legumes stover incorporation increases the grain and stover yield and $\mathrm{N}$-uptake by the rotational maize crop grown in the subsequent season. The benefit to the maize crop from previous cropping with the legume differed widely according to the nature of the legume. This is probably due to the combined effects of the amount of $\mathrm{N}$ input from biological nitrogen fixation by the legume, the amount of crop residue production, the nitrogen harvest indices (NHI) and the degree of lignification (\% lignin content) in the residues. It can also further be concluded that communal farmers could still improve their maize yields by growing it in rotation with legumes even with stover removal because the maize yield and N-uptake from the plots where legumes stover were removed were significantly higher than those of the maize after maize or after fallow plots. The legumes crop residues can be used as livestock supplementary fodder during winter when veldt grazing becomes scarce. 


\section{Acknowledgements}

This research was conducted under the "Agricultural Biotechnology Programme for Resource Poor Farmers (ZimbabweNetherlands Cooperation). The authors are very grateful to the Netherlands Ministry for Development Cooperation for providing financial support.

\section{References}

Boddey, R.M., K.E. Giller, G. Cadisch, B.J.R. Alves, and S. Urquiaga. 1997. Contribution of Biological Nitrogen Fixation to Tropical Agriculture: Actual and Potential, In: Biological Nitrogen Fixation for the $21^{\text {st }}$ century. Proceedings of the $11^{\text {th }}$ International Congress on Nitrogen Fixation, Institut Pasteur, Paris, France, July 20-25, 1997, Elmerich C, Kondorosi A, and Newton WE [eds.]. Kluwer Academic Publishers, the Netherlands, pp. 98-102.

Giller, K.E. and K.J. Wilson. 1991. Nitrogen Fixation in Tropical Cropping Systems, CAB International, Wallingford, England, pp. 167-237.

Giller, K.E., J.F. Mcdonagh, G. Cadisch. 1993. Can biological nitrogen fixation sustain agriculture in the tropics? In: Soil Science and Sustainable Land Management in the Tropics, Syers, JK and Rimmer DL [eds.], CAB International, Wallingford, England, pp. 173-191.

Giller, K.E. and G. Cadisch. 1995. Future benefits from biological nitrogen fixation: An ecological approach to agriculture, Plant and Soil Vol. 174, pp.255-277.

Giller, K.E., G. Cadisch, C. Ehaliotis, E. Adams, W.D. Sakala, and P.L. Mafongoya. 1997. Building soil nitrogen capital in Africa, American Society of Agronomy and Soil Science of America, USA, Replenishing soil fertility in Africa, SSSA Special Publication Vol. 51, pp. 151-157.

Kasasa, P., S. Mpepereki, and K.E. Giller. 1998. Nodulation and yield of promiscuous soyabean (Glycine max L. Merr.) varieties under field conditions, In: Soil fertility research for maize-based farming systems in Malawi and Zimbabwe, Waddington SR, Murwira HK, Kumwenda JDT, Hikwa D, and Tagwira F [eds.], Harare, Zimbabwe, pp. 99-104.

Kipe-Nolt, J.A. and K.E. Giller. 1993. A field evaluation using 15N isotope dilution method of lines of Phaseolus vulgaris L. bred for increased nitrogen fixation, Plant and Soil, Vol. 152, pp. 107-114.

Lane, P.W. and R.W. Payne. 1987. Genstat 5 Reference Manual, Oxford University Press, New York, United States of America, 218pp.

McDonagh, J.F., B. Toomson, V. Limpinutana, and K.E. Giller. 1993. Estimates of the residual nitrogen benefit of groundnut to maize in Northeast Thailand, Plant and Soil, Vol. 154, pp. 267-277.

Mukurumbira, L.M. 1985. Effects of rate of fertilizer nitrogen and previous grain legume crop $\quad$ on maize yields. Zimbabwe Agricultural Journal, Vol. 82, pp. 177-179.

Mpepereki, S. 1994. Characterization studies of rhizobial in some Zimbabwean soils. PhD thesis, University of Zimbabwe, Harare, Zimbabwe, 239pp.

Peoples, M.B. and D.F. Herridge. 2000. Quantification of Biological Nitrogen Fixation in Agricultural Systems, Nitrogen Fixation: Proceedings of the $12^{\text {th }}$ International Congress on Nitrogen Fixation, Foz do Iguacu, Parana, Brazil,September 1217, 1999. Pedrossa FO, Hungria M, Yates G, and WE Newton [eds.], Kluwer Academic Publishers, The Netherlands, pp. 26-31.

Svubure, O. 2000. Contributions of Biological Nitrogen Fixation (BNF) by selected grain legumes to sustainability of the maizebased cropping systems in communal areas of Zimbabwe, MPhil. thesis, University of Zimbabwe, Harare, Zimbabwe, 137pp.

Toomsan, B., J.F. McDonagh, V. Limpinutana, and K.E. Giller. 1995. Nitrogen fixation by groundnut and soyabean and residual nitrogen benefits to rice in farmers' fields in northeastern Thailand, Plant and Soil, Vol. 175, pp. 45-56.

\section{Biographical notes}

Oniward Svubure is a soil scientist/agronomist. Since late 2003, he is with the Chinhoyi University of Technology, one of the state universities in Zimbabwe as is a senior lecturer and chairperson of the Department of Irrigation and Water Engineering. He holds a Bsc (Hons.) in Agriculture (University of Zimbabwe, UZ, 1988), an MPhil in Agriculture (UZ, 2001), an MSc in Water Resources Management (UNESCO-IHE, Delft, The Netherlands, 2007) and a Diploma in Marketing Management from the Institute of Marketing Management, IMM (South Africa, 1996). His research interest is in sustainable cropping systems and modeling, smallholder irrigation development, water resources management and climate change and adaptation.

Sheunesu Mpepereki is a Professor of Soil Science in the Department of Soil Science \& Agricultural Engineering, University of Zimbabwe, Zimbabwe. He has more than twenty-two years of university teaching and research. His area of research includes soil productivity and fertility management, bio-fertilizers, Rhizobium inoculants technology and legume-cereal rotation cropping systems. He has published more than thirty-five papers in refereed journals, supervised more than ten $\mathrm{PhD}$ students, presented several conferences papers and has written two books informed by his research work.

Fred Makonese is a Senior Lecturer in the Department of Soil Science \& Agricultural Engineering, University of Zimbabwe, Zimbabwe. He has more than five years of university teaching and research. His research interest includes Mycorrhizael inoculants for trees, soil fertility management and bio-fertilizers.

Received August 2010

Accepted September 2010

Final acceptance in revised form October 2010 